\title{
Consumers' willingness to purchase three alternatives to meat proteins in United Kingdom, Spain, the Dominican Republic and Brazil
}

by Gomez-Luciano, C.A., De Aguiar, L., Vriesekoop, F. and Urbanc, B.

Copyright, publisher and additional information: This is the author accepted manuscript. The final published version (version of record) is available online via Elsevier.

This version is made available under the CC-BY-ND-NC licence:

https://creativecommons.org/licenses/by-nc-nd/4.0/legalcode

Please refer to any applicable terms of use of the publisher

DOI: https://doi.org/10.1016/j.foodqual.2019.103732

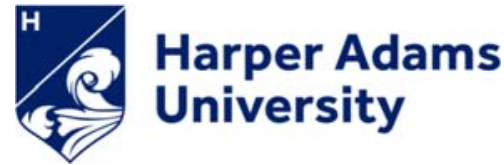

Gomez-Luciano, C.A., De Aguiar, L., Vriesekoop, F. and Urbanc, B. 2019. Consumers' willingness to purchase three alternatives to meat proteins in United Kingdom, Spain, the Dominican Republic and Brazil. Food Quality and Preference. 
3

4

5

6

7

8

Consumers' willingness to purchase three alternatives to meat proteins in the United Kingdom, Spain, Brazil and the Dominican Republic

\author{
Cristino Alberto Gómez-Luciano ${ }^{1}$, Luis Kluwe de Aguiar $^{2}$, Frank Vriesekoop ${ }^{2 *}$, Beatriz
} Urbano $^{3}$.

\begin{abstract}
One of the current trends in dietary preferences involves the transition to a low- or reduced-meat diet, which is often desirable for health and environmental reasons. This change in dietary preferences requires an in-depth insight into consumers' preferences towards a variety of alternative/non-meat proteins. This study aimed to investigate the consumers' preferences and willingness to purchase three alternative dietary protein sources, namely plant-, cultured meat- and insect-based proteins in four countries with dissimilar economic development status (the United Kingdom, Spain, Brazil and the Dominican Republic). It also aimed to determine which factors would most-influence the willingness to purchase. From a total sample of 729 valid respondents, psychographic variables were analysed. The alternative protein deemed the respondents' most preferred willing to purchase was the plant-based type since that option tended to be more widely available in the market. Among the analysed economic groups, the countries classified in the higher economic groups tended to show more readiness to replace traditional meats for the three alternatives. Models suggest that the respondents regarded the alternative characteristics and/or the attributes compared to meat as being the most important factors that influence their willingness to purchase rather than environmental, convenience or healthy buying decisions, or a low level of neophobia. If the perception of healthiness, safety and nutritiousness increases one-unit for the cultured meat in Brazil, the probability of willingness to purchase would increase $86.82 \%$. One-unit stronger belief in Spanish that plant-based are healthy, safe and nutritious higher the probability of willingness to purchase $68.74 \%$. One-unit higher perceive the characteristics of healthiness, safety and nutritional content of the insectsbased products would increase $68 \%$ the probability of willingness to purchase in the United Kingdom, 72\% in Brazil and 58\% in the Dominican Republic.
\end{abstract}

Keywords: Consumers' attitudes; psychographics; meat-alternative perceptions; plantbased proteins; cultured meat-based proteins; insect-based proteins.

${ }^{1}$ Specialized Institute of Higher Studies Loyola. San Cristóbal. Dominican Republic.

${ }^{2}$ Department of Food Technology and Innovation. Harper Adams University. Newport. Shropshire, TF10 8NB. United Kingdom.

${ }^{3}$ Department of Agriculture and Forestry Engineering. University of Valladolid. Palencia. Spain.

* Corresponding author. Email: fvriesekoop@harper-adams.ac.uk 


\section{Introduction}

Low-meat diets are becoming increasingly popular for various health reasons and to reduce the cost of climate change mitigation (de Boer, Schösler \& Aiking, 2014; Sabaté \& Soret, 2014; Schösler, de Boer, Hoogland \& Boersema, 2007). In order to achieve this, alternative protein sources are being explored as possible substitutes for traditional meat (Verbeke, Sans \&Van Loo, 2015). However, the public's preferences and the consumers' responses remain largely unknown. Although, trends towards eating less meat have been observed and labelled under different terms in the literature, i.e., meatreduced diet (Hayley, Zinkiewicz \& Hardiman, 2015), flexitarianism (Raphaely \& Marinova, 2014), semi-vegetarianism (Clarys et al., 2014) or conscious omnivorism (Rothgerber, 2015). More research is needed to ascertain consumers' food patterns and mechanisms so that an effective transition to sustainable low-meat diets could be achieved. Due to the overall popularity of meat in diets, the transition to a low-meat diet has the potential to cause a profound societal transformation. As such, it is essential to know that products derived from novel non-meat proteins mitigate the environmental and animal welfare concerns (Gerber et al., 2013), and provide a healthy diet that will be acceptable to consumers (Schösler, de Boer \& Boersema, 2012).

In light of the context mentioned above, the consumers' preferences towards three different non-meat dietary proteins, including plant-, cultured meat- and insect-based proteins, were investigated in this study. Plant-based proteins are a well-ingrained and growing market segment, and constitute the majority of meat replacement products (de Boer \& Aiking, 2011). Cultured or in vitro meat is derived from a biotechnological tissue-culture approach, which produces animal proteins on an industrial scale, and is being developed and launched in several different countries (Keefe, 2018; Post, 2014). Insect-based proteins, deemed as an alternative that delivers high protein content, are regulated under novel foods legislation in the European Union and being promoted in many western countries (Lombardi, Vecchio, Borrello, Caracciolo \& Cembalo, 2018; Verbeke, 2015). To the best of our knowledge, no previous research has analysed the consumers' preferences towards these three alternatives to conventional meat, simultaneously, but rather one at a time (Goodwin \& Shoulders, 2013; Post, 2014; Schösler et al., 2012; Verbeke et al., 2015). Hence, this study provides a more realistic approach to consumers' decision-making processes regarding alternative dietary protein sources since the consumers evaluate and decide among a range of alternatives (Symmank et al., 2017). Furthermore, this study allows an insight into the preferences and aversions towards various alternative dietary protein sources, across multiple nations.

Plant-based meat substitutes are well established in the market and, hence, represent one alternative to animal proteins for containing the bulk of their calories from plant materials. In comparison to conventional meat, plant-based proteins are deemed to be less detrimental to the environment (de Boer \& Aiking, 2011), healthier (Sabaté, 2003) and prevent animal suffering (Foer, 2010). Several factors highlighted in the literature 
that positively affect the adoption of a plant-based diet include gender, age, education (Graça, Oliveira \& Cardoso, 2015), vegetable preparation skills and familiarity with suitable plants (Schösler et al., 2012), situations of weight control (de Boer et al., 2014; Herman \& Polivy, 2008), health (Gerber et al., 2013; Sadler, 2004; Tilman \& Clark, 2014), environmental sustainability concerns (de Boer et al., 2014; Sabaté \& Soret, 2014; Tilman \& Clark, 2014), ethical considerations (de Boer et al., 2007), animal welfare concerns (Bryant \& Barnett, 2018), naturalness (Sadler, 2004) and physiological factors, such as low bitter taste sensitivity (Drewnowski \& GomezCarneros, 2000) and trendiness/peer-pressure (Schösler et al., 2012).

Cultured meat grown from bovine skeletal muscle stem cells using tissue-engineering techniques has also been developed as an effective, sustainable, potential meat source (Arshad et al., 2017; Post, 2014). The main factors affecting the adoption or rejection of this novel product appear to be related to contextual factors, such as media coverage (Goodwin \& Shoulders, 2013), trust in science, policy and society, public involvement (Verbeke et al., 2015) and comparative price and sensory expectations (Adámek, Mlček, Borkovcová \& Bednářová, 2018; Verbeke et al., 2015).

Finally, this research also considers insects as a potential alternative protein source to conventional meat. Due to the high nutritional value and protein-rich nature, insects have historically and regularly been used as a part of the diet of a variety of cultures (Ramos-Elorduy, 1997). Entomophagy is now gaining acceptance in western society (Lombardi et al., 2018; van Huis, 2017; Verbeke, 2015), especially among wealthy urban dwellers, who consider it a gourmet dish or delicacy. Verbeke et al. (2015) found that gender, age, familiarity, convenience, environmental food choice motives, meatrelated attitudes, future consumption intentions and food neophobia worked as significant predictors for western consumers adopting or rejecting insects as meat substitutes.

Nevertheless, it remains largely unknown how consumers will react to the uptake of alternative proteins and whether, and under which conditions, consumers would be willing to purchase these non-meat proteins. For example, in a study in the Netherlands, respondents indicated that $63 \%$ supported the development of cultured meat, but only $23 \%$ of the respondents answered 'certainly' when asked whether they would buy cultured beef (Post, 2014). For this reason, the present study analyses the willingness to purchase $(\mathrm{WTPu})$ three alternative dietary protein sources, rather than focusing on the "willingness to try" or "consider" alternatives to meat proteins, as studied elsewhere (Verbeke et al., 2015).

In order to gain insight into the consumers' ${ }^{`}$ WTPu three alternative dietary protein sources, the concept of psychographic motivations driving consumers' choices served as a framework. Furthermore, scales that capture specific attitudinal aspects of consumers that could inhibit or motivate their WTPu alternative dietary proteins were used. Current literature has identified a general distrust of novel foods and caution towards novel food 
technologies as important attitudinal barriers for consumption of some alternatives to conventional meat proteins (House, 2016). Moreover, the environmental impact of food choice, convenience, as well as interest in the health characteristic, are main consumers' concerns that appear important in motivating the consumption of alternative proteins sources compared with conventional meat (Tilman \& Clark, 2014; Verbeke et al., 2015). Sensory expectations and product characteristics of alternative dietary proteins compared with conventional meat have also been documented (Verbeke et al., 2015). In the present study, several variables were investigated, using validated scales consistent with the experimental design, such as the Food Neophobia Scale (FNS; Pliner \& Hobden, 1992), Food Technology Neophobia Scale (FTNS; Cox \& Evans, 2008), attitudes towards healthiness of foods (Roininen, Lähteenmäki \& Tuorila, 1999), attention to the environmental impact of the consumers' food choices (Roberts, 1996; Verbeke et al., 2015), and the convenience orientation in relation to food and its preparation (Candel, 2001).

It is natural to expect the transition towards a low-meat diet to differ from country-tocountry (Schnettler et al., 2013) and between different consumer segments. Therefore, it is necessary to address consumers regarding their individual preferences and WTPu (de Boer et al., 2014). Much of the literature shows that research on meat substitution has focused on developed countries (de Boer et al., 2014; Graça et al., 2015; Sabaté \& Soret, 2014; Schösler et al., 2012). In contrast, little research has been carried out in developing countries where rising incomes and urbanisation are driving a rapid increase in meat consumption (Tilman \& Clark, 2014). Consequently, there is a lack of empirical studies that focus on countries classified in different economic groups. Therefore, this research aims at comparing consumers' preferences and WTPu alternative/non-meat proteins in four countries (the United Kingdom [UK], Spain [SP], Brazil [BR] and the Dominican Republic [DR]). For the purpose of this study, the countries were selected based on a ranking of 100 countries, as proposed by Tilman \& Clark (2014), according to their 2000-2007 average per capita real gross domestic product (in 1990 international dollars). Each of the countries selected belonged to the first four economic groups: the UK as part of Group A (top 15 countries), SP in Group B, BR in Group C and, finally, the DR in Group D. According to Tilman \& Clark (2014), the top richest 15 nations (Group A) had a 750\% greater per capita demand for meat protein from ruminants, seafood, poultry and pork than the bottom 24 poorest nations (Group F).

Despite meat consumption being highest in high-income countries (FAO, 2019), changes in meat consumption in high-income countries have been sluggish, stagnating in many, or even decreasing in some over the last 50 years. The average annual meat consumption per person in the UK was $69.24 \mathrm{~kg}$ in 1961 and $81.48 \mathrm{~kg}$ in 2013 (FAO, 2019). This trend constitutes a relatively slow increase in meat consumption by the British (Table 1). In SP, the average consumption was $21.78 \mathrm{~kg}$ in 1961 and $94.04 \mathrm{~kg}$ in 2013, which represents a substantially large, relative increase (4.32-fold) in meat consumption between 1961 and 2013. However, meat consumption in SP peaked in 2000 at $113.25 \mathrm{~kg}$ per person, which represents a greater than 5-fold increase since 1961 
(FAO, 2019). The increase in per capita meat consumption has been most marked in countries that have undergone a strong economic transition, for example, the per capita consumption in BR has nearly quadrupled in the same period (from $27.49 \mathrm{~kg}$ in 1961 to $97.58 \mathrm{~kg}$ in 2013) while meat consumption in the DR was $15.34 \mathrm{~kg}$ in 1961 and $47.2 \mathrm{~kg}$ in 2013 (FAO, 2019). In the same period, South American meat production grew more than six-fold, from 7.17 million tonnes in 1961 to 41.45 million tonnes in 2014 (FAO, 2019). The Caribbean meat output has approximately tripled, from 395,556 tonnes to 1.21 million tonnes while in Europe, the meat output has just about doubled in the same period.

Table 1. Meat consumption: kg per person per year by country, fold increase from 1961 and 2013.

Source: United Nations Food and Agriculture Organisation (FAO, 2019).

\begin{tabular}{|c|c|c|c|c|c|c|c|}
\hline \multirow{2}{*}{ Country } & \multicolumn{6}{|c|}{ Year } & \multirow{2}{*}{$\begin{array}{l}\text { Fold increase } \\
1961-2013\end{array}$} \\
\hline & 1961 & 1970 & 1980 & 1990 & 2000 & 2013 & \\
\hline United Kingdom & 69.24 & 72.64 & 70.64 & 72.51 & 77.06 & 81.49 & 1.17 \\
\hline Spain & 21.78 & 46.15 & 70.38 & 96.66 & 113.25 & 94.04 & 4.32 \\
\hline Brazil & 27.49 & 30.47 & 41.00 & 52.64 & 78.98 & 97.58 & 3.55 \\
\hline Dominican Republic & 15.34 & 15.29 & 24.36 & 30.44 & 40.00 & 47.20 & 3.08 \\
\hline
\end{tabular}

The aim of this study was to provide insight into consumer preferences and the WTPu any of three alternative dietary protein sources (plant-, cultured meat- and insect-based proteins) in the UK, SP, BR and the DR. Furthermore, we aimed to determine the important factors most likely influencing the WTPu. In doing so, we hope to predict the purchase of these three non-meat dietary proteins in achieving low-meat diets.

\section{Material and methods}

\subsection{Data collection and sample}

A sample of 983 responses in total was obtained. It consisted of 366 respondents from the UK (from which a sub-sample of 180 responses validated the country population), 200 from SP, 216 from BR and 201 from the DR (from which a sample of 133 validated the country population). A valid sample of 729 respondents was used. The sociodemographic characteristics of the participants are presented in Table 2.

Table 2. Socio-demographics profile of the consumers's sample $(n=729)$ expressed as a percentage $(\%)$ of each sub-sample with respect to the country population (World Bank, 2019).

\begin{tabular}{|c|c|c|c|c|c|c|c|c|c|}
\hline \multirow[b]{2}{*}{ Variable } & \multirow[b]{2}{*}{ Cases } & \multicolumn{2}{|c|}{ United Kingdom } & \multicolumn{2}{|l|}{ Spain } & \multicolumn{2}{|l|}{ Brazil } & \multicolumn{2}{|c|}{ Dominican Republic } \\
\hline & & $\begin{array}{l}\text { Sample } \\
\mathrm{n}=180\end{array}$ & $\begin{array}{c}\text { World Bank } \\
\text { data }\end{array}$ & $\begin{array}{l}\text { Sample } \\
\mathrm{n}=200\end{array}$ & $\begin{array}{c}\text { World Bank } \\
\text { data }\end{array}$ & $\begin{array}{l}\text { Sample } \\
\mathrm{n}=216\end{array}$ & $\begin{array}{c}\text { World Bank } \\
\text { data }\end{array}$ & $\begin{array}{l}\text { Sample } \\
\mathrm{n}=133\end{array}$ & $\begin{array}{c}\text { World Bank } \\
\text { data }\end{array}$ \\
\hline \multirow[t]{3}{*}{ Gender } & Male & 48.3 & 49.3 & 50.5 & 51.0 & 43.1 & 49.1 & 47.4 & 48.6 \\
\hline & Female & 51.7 & 50.7 & 47.0 & 49.0 & 56.9 & 50.9 & 50.4 & 51.4 \\
\hline & Prefer no answer & 0.0 & & 2.5 & & 0.0 & & 2.2 & \\
\hline \multirow[t]{4}{*}{ Age } & $0-24$ years & 35.0 & 29.6 & 28.5 & 25.0 & 25.8 & 39.2 & 51.1 & 45.4 \\
\hline & $25-54$ years & 48.9 & 40.8 & 56.0 & 45.3 & 58.0 & 43.8 & 45.1 & 39.5 \\
\hline & $55-64$ years & 13.9 & 11.8 & 8.0 & 11.9 & 11.1 & 8.9 & 2.3 & 7.7 \\
\hline & $\geq 65$ & 2.2 & 17.8 & 7.5 & 17.8 & 5.1 & 8.1 & 1.5 & 7.4 \\
\hline \multirow[t]{2}{*}{ Food allergies } & Yes & 22.4 & & 12.0 & & 19.4 & & 17.2 & \\
\hline & No & 77.6 & & 88.0 & & 80.6 & & 82.8 & \\
\hline
\end{tabular}


The participants responded to a combination of digital and paper versions of the same surveys. Data collection started in February 2017 and finished in October 2017. The questionnaire was firstly written in English and was then translated into Castilian Spanish, Dominican Spanish and Brazilian Portuguese by native speakers fluent in both English and their native language (the authors), to improve the accuracy of meaning and avoid misunderstandings by the various lingual cohorts. The translated versions were back-translated into English to ensure that the meaning had not deviated from the initial wording. The research collaborators from each country were responsible for rolling out the survey at a national level while all data gathered was centrally collected and collated at Harper Adams University (HAU) in the UK. Additionally, as part of the ethics declaration, each questionnaire also included a contact e-mail at HAU, so that questions arising from answering the questionnaire could be addressed. For each country, the most appropriate data gathering method was selected. In the UK and BR, social media and existing contact lists were used to distribute the digital questionnaire by e-mail. In SP, the digital questionnaire was launched in a similar fashion as in the UK and BR; however, some older respondents requested and were presented with a paper version of the questionnaire. In the DR, data were mainly collected through using a paper version of the questionnaire, which is a reflection of the relatively scant access to the digital questionnaire.

\subsection{Questionnaire and scaling}

The questionnaire included various distinct groups of questions and statements consistent with the study's sub-objectives. The survey was approved by the HAU Research Ethics Committee. Before answering any questions, all participants were asked to acknowledge an informed consent statement.

The first group of statements probed the respondents' attitudes towards new foods, new food technologies, health, convenience and environmental impact of food choices. More specifically, the following survey tools were used in the questionnaire to measure the variables: the FNS (10 items that were merged into one food neophobia score named FNS) (Pliner \& Hobden, 1992); the FTNS (6 items that were merged into one FTNS score) (Cox \& Evans, 2008); healthiness of food choices (3 items that were merged into one score named "impact of the healthiness of food choices") (Roininen et al., 1999); convenience orientation in relation to food (4 items that were merged into one score named "convenience in relation of the food") (Candel, 2001); consumer attention to the environmental impact on food choices ( 5 items that were merged into one score named "environmental impact of food choices") (Roberts, 1996; Verbeke, 2015). These questions were presented in the form of statements to which the respondents expressed their opinion using a five-point Likert scale ranging from 1 ("strongly disagree") to 5 ("strongly agree") (Table 3). 
Table 3. Order, variables, questions and scale of the first block question of food neophobia scale (FNS), food technology neophobia scale (FTNS), health, convenience and environmental impact of food choices.

\begin{tabular}{|c|c|c|c|}
\hline Order & Variable & Question & Scale \\
\hline 1 & FNS & I am constantly sampling new and different foods & {$[1 ; 5]$} \\
\hline 2 & FNS & I do not trust new foods & {$[1 ; 5]$} \\
\hline 3 & FNS & I like foods from different countries & {$[1 ; 5]$} \\
\hline 4 & FNS & If I do not know what is in a food, I will not eat it & {$[1 ; 5]$} \\
\hline 5 & FNS & At dinner parties, I will try a new food & {$[1 ; 5]$} \\
\hline 6 & FNS & Some foods look too weird to eat & {$[1 ; 5]$} \\
\hline 7 & FNS & I am afraid to eat things I have never had before & {$[1 ; 5]$} \\
\hline 8 & FNS & I am very particular about the foods I eat & {$[1 ; 5]$} \\
\hline 9 & FNS & I will eat almost anything & {$[1 ; 5]$} \\
\hline 10 & FNS & I like to try new foods from all over the world & {$[1 ; 5]$} \\
\hline 11 & FTNS & The benefits of new food technologies are often grossly overstated & {$[1 ; 5]$} \\
\hline 12 & FTNS & $\begin{array}{l}\text { There are plenty of tasty foods around so we do not need to use new food } \\
\text { technologies to produce more }\end{array}$ & {$[1 ; 5]$} \\
\hline 13 & FTNS & New food technologies decrease the natural quality of foods & {$[1 ; 5]$} \\
\hline 14 & FTNS & $\begin{array}{l}\text { The media (TV, radio, newspapers, magazines, internet sources, etc.) usually } \\
\text { provide a balanced and unbiased view of new food technologies }\end{array}$ & {$[1 ; 5]$} \\
\hline 15 & FTNS & New products using new food technologies can help people have a balanced diet & {$[1 ; 5]$} \\
\hline 16 & FTNS & $\begin{array}{l}\text { Innovations in food technology can help us produce foods in a sustainable } \\
\text { manner }\end{array}$ & {$[1 ; 5]$} \\
\hline 17 & $\begin{array}{l}\text { Impact of the healthiness } \\
\text { of food choices }\end{array}$ & The healthiness has little impact on my food choices & {$[1 ; 5]$} \\
\hline 18 & $\begin{array}{l}\text { Impact of the healthiness } \\
\text { of food choices }\end{array}$ & I am very particular about the healthiness of the food I eat & {$[1 ; 5]$} \\
\hline 19 & $\begin{array}{l}\text { Impact of the healthiness } \\
\text { of food choices }\end{array}$ & I eat what I like, and I do not worry much about its healthiness & {$[1 ; 5]$} \\
\hline 20 & $\begin{array}{l}\text { Convenience in relation of } \\
\text { the food }\end{array}$ & The less I have to do to prepare a meal - the better! & {$[1 ; 5]$} \\
\hline 21 & $\begin{array}{l}\text { Convenience in relation of } \\
\text { the food }\end{array}$ & $\begin{array}{l}\text { I love cooking and will spend a lot of time and effort to prepare foods on a daily } \\
\text { basis }\end{array}$ & {$[1 ; 5]$} \\
\hline 22 & $\begin{array}{l}\text { Convenience in relation of } \\
\text { the food }\end{array}$ & At home, I preferably eat meals that can be prepared quickly & {$[1 ; 5]$} \\
\hline 23 & $\begin{array}{l}\text { Convenience in relation of } \\
\text { the food }\end{array}$ & Even though I live a busy life, whenever possible, I love to cook and bake & {$[1 ; 5]$} \\
\hline 24 & $\begin{array}{l}\text { Environmental impact of } \\
\text { food choices }\end{array}$ & $\begin{array}{l}\text { When I buy foods, I try to consider how my use of them will affect the } \\
\text { environment }\end{array}$ & {$[1 ; 5]$} \\
\hline 25 & $\begin{array}{l}\text { Environmental impact of } \\
\text { food choices }\end{array}$ & $\begin{array}{l}\text { I am worried about humankind's ability to provide the nutritional needs of the } \\
\text { current world's population }\end{array}$ & {$[1 ; 5]$} \\
\hline 26 & $\begin{array}{l}\text { Environmental impact of } \\
\text { food choices }\end{array}$ & Something drastic has to change in order to feed all the people on earth by 2050 & {$[1 ; 5]$} \\
\hline 27 & $\begin{array}{l}\text { Environmental impact of } \\
\text { food choices }\end{array}$ & $\begin{array}{l}\text { The world can easily sustain the food demands of a growing population in one or } \\
\text { two generations time }\end{array}$ & {$[1 ; 5]$} \\
\hline 28 & $\begin{array}{l}\text { Environmental impact of } \\
\text { food choices }\end{array}$ & Global warming is a fad, dreamt up by a bunch of hippies & {$[1 ; 5]$} \\
\hline
\end{tabular}

255 The second group of statements probed the consumers' perceptions of the likely health 256 and nutritional benefits of meat, and their opinion on the sensory experience (Table 4).

Table 4. Order, variables, questions and scale of the perception of health and nutritional benefits of meat and sensory experience.

\begin{tabular}{llll}
\hline Order & Variable & Question & Scale \\
\hline 29 & $\begin{array}{l}\text { Meat is necessary for obtaining beneficial } \\
\text { nutrients }\end{array}$ & Eating meat is necessary for obtaining beneficial nutrients & {$[1 ; 5]$} \\
30 & $\begin{array}{l}\text { Meat is an important part of a healthy and } \\
\text { balanced diet }\end{array}$ & $\begin{array}{l}\text { The nutritional benefits of meat can easily be matched by } \\
\text { alternative protein sources }\end{array}$ & {$[1 ; 5]$} \\
31 & $\begin{array}{l}\text { The nutritional benefits of meat can easily } \\
\text { be matched by alternative protein sources }\end{array}$ & Meat is an important part of a healthy diet & {$[1 ; 5]$} \\
32 & Taste & The taste of meat is important to me & \\
33 & Texture & The texture of meat is important to me & {$[1 ; 5]$} \\
34 & Smell & The smell of meat is important to me & {$[1 ; 5]$} \\
\hline
\end{tabular}

Following that, the questionnaire included descriptions of the three alternatives to meat proteins that formed the basis of this study, namely, plant-, cultured meat- and insect- 
into one score named " $\mathrm{X}$ " characteristics), attitude towards sustainability, the taste and price relative to conventional meat ( 3 items that were merged into one score named " $\mathrm{X}$ " versus traditional characteristics) (Table 5).

Table 5. Order, variables, questions and scale of the characteristics of the three alternatives to meat proteins. "X" (the alternative protein): plant-, cultured meat- and insect-based alternative protein foods.

\begin{tabular}{|c|c|c|c|}
\hline Order & Variable & Question & Scale \\
\hline 35 & Consider & Would you consider $\mathrm{x}$-alternative protein as a source of dietary proteins? & {$[1 ; 5]$} \\
\hline 36 & "X" characteristics & "X" is healthy & {$[1 ; 5]$} \\
\hline 37 & "X" characteristics & " $\mathrm{X} "$ is safe to eat & {$[1 ; 5]$} \\
\hline 38 & "X" characteristics & " $\mathrm{X}$ " is nutritious & {$[1 ; 5]$} \\
\hline 39 & $\begin{array}{l}\text { "X" versus traditional } \\
\text { characteristics }\end{array}$ & " $\mathrm{X}$ " is much more sustainable than traditional meat & {$[1 ; 5]$} \\
\hline 40 & $\begin{array}{l}\text { "X" versus traditional } \\
\text { characteristics }\end{array}$ & " $\mathrm{X}$ " is much tastier than traditional meat & {$[1 ; 5]$} \\
\hline 41 & $\begin{array}{l}\text { "X" versus traditional } \\
\text { characteristics }\end{array}$ & " $\mathrm{X}$ " is much cheaper than traditional meat & {$[1 ; 5]$} \\
\hline 42 & Try & Would you personally be willing to try " $\mathrm{X}$ "? & {$[1 ; 5]$} \\
\hline 43 & Purchase & Would you personally be willing to purchase "X"? & {$[1 ; 5]$} \\
\hline 44 & Pay more & Would you personally be willing to pay more for "X"? & {$[1 ; 5]$} \\
\hline
\end{tabular}

271

272

273

274

275

276

277

278

279

280

281

282

283

284

285

286

287

288

289

290

291

292

293

294

295

296

297

298

299

The questionnaire also inquired about the respondent's gender and age demographic characteristics.

\subsection{Data analysis}

WTPu was analysed as a discrete decision (yes/no) (see also Verbeke, 2015) by specifying the response categories "totally agree" and "agree" as "yes" and the other response categories as a "no". Considering consumers' WTPu alternative proteins as a substitute for meat as a binary choice is consistent with the recommendation by Hoek et al. (2011) who suggest using this kind of dichotomous seeker/avoider segmentation when the product category is not frequently purchased and/or when there is a strong attitude towards product category. Both conditions are clearly fulfilled for consumers' attitudes towards these alternatives to meat proteins.

To model this dichotomous decision we used a binary logistic regression (Verbeke, 2015) after a principal component analysis (PCA). PCA was used to reduce the variables and eliminate the possible multicollinearity among variables (Rahayu, Sugiarto, Madu, Holiawati \& Subagyo, 2017). From each component of the PCA, the highest loads of the eigenvectors were selected as predictors to model current WTPu. Then, binary logistic regression was used to predict the odds of being WTPu based on the values of the predictors. Regression coefficients were estimated using maximum likelihood estimation and were presented with Wald $\chi^{2}$-statistics and as odds ratios, by using the Wald forward stepwise method. The models revealed the most important predictor/s of WTPu the alternative to meat proteins and predicted future WTPu. SPSS v.23 software was used.

To compare the variation of the variables between countries against the variation within groups we used an analysis of variance (ANOVA). The statistically significant 
327

differences between countries means were determined ( $\mathrm{F}$ and $p$-value). The significance $(p<0.05)$ was obtained using Levene's test. Following that, Fisher's least significant difference (LSD) post hoc test was used to explore all possible pair-wise means of the countries' comparisons to identify which pair of countries was statistically different.

To test the likely correlation between independent variables, the bivariant Pearson correlation was used $(p<0.05)$. As such the bivariant Pearson correlation was employed to test the variables of perception of the importance and benefits of meat (Verbeke, 2015), and the benefits of the alternatives to conventional meat existed, and to test correlations among the WTPu plant-, cultured meat- and insect-based protein foods.

\section{Results}

\subsection{Descriptive statistics}

The number of respondents who believed that the alternative protein sources could readily match the nutritional benefits of meat ranged from $20.8 \%$ (BR) to $53.8 \%$ (the UK). When considering whether meat was an important part of a healthy and balanced diet, the British respondents indicated it to be significantly less than respondents from SP, the DR or BR $(p=0.000)$ (Table 7). The correlation test showed an increase in the belief that meat is needed for obtaining beneficial nutrients and a healthy diet decreased the view that the nutritional benefits of meat could easily be matched by alternative proteins sources (Pearson's correlation $r=-0.363$ and $r=-0.506$, respectively, both $p=0.000)$.

Table 7. The need and importance of meat, the benefits of alternative protein sources and sensorial importance of meat expressed as mean \pm standard deviation. ANOVA ( $\mathrm{F}$ and $p$-values) by rows indicates the significant differences for each variable among countries. Different superscript letters across the same variable denote a significant difference between countries $(p<0.05)$, n.s. = "not significant".

\begin{tabular}{|c|c|c|c|c|c|c|}
\hline Variable & $\begin{array}{l}\text { United } \\
\text { Kingdom }\end{array}$ & Spain & Brazil & $\begin{array}{l}\text { Dominican } \\
\text { Republic }\end{array}$ & $\mathrm{F}$ & $p$ \\
\hline 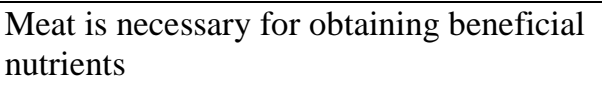 & $3.38 \pm 1.23^{\mathrm{a}}$ & $2.36 \pm 1.06^{\mathrm{b}}$ & $3.70 \pm 1.12^{\mathrm{c}}$ & $2.76 \pm 1.12^{\mathrm{d}}$ & 56.660 & 0.0 \\
\hline $\begin{array}{l}\text { Meat is an important part of a healthy and } \\
\text { balanced diet }\end{array}$ & $3.06 \pm 1.29^{\mathrm{a}}$ & b & 3 & 3 & 13.936 & 0.000 \\
\hline $\begin{array}{l}l \text { benefits of meat can easily } \\
\text { y alternative protein sources }\end{array}$ & 3.3 & & 3 & & n.s. & n.s. \\
\hline Taste & & & & 4.37 & 7.257 & 0.000 \\
\hline & & & & & 6.978 & 0.000 \\
\hline Smell & $3.69 \pm 1.34^{\mathrm{a}}$ & $4.26 \pm 0.84^{b}$ & $3.98 \pm 1.14^{\mathrm{c}}$ & $4.43 \pm 0.88^{b}$ & 14.665 & 0.000 \\
\hline
\end{tabular}

The WTPu alternative dietary proteins ranged from $36.7 \%$ in the DR to $58.5 \%$ in the UK for plant-based proteins, and from $11.5 \%$ in BR to $42 \%$ in SP for cultured meatbased proteins, as well as from $6.9 \%$ in BR to $23.5 \%$ in the UK for insect-based food (Figure 1). 


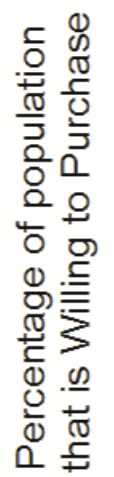

Figure 1. Willingness to purchase plant-, cultured meat- and insect-based protein foods in the United Kingdom (UK), Spain (SP), Brazil (BR) and the Dominican Republic (DR).

In almost all instances, plant-based proteins scored the highest in regards to the various characteristics (Table 8). For healthiness, safety, sustainability and expected cost, the respondents from the UK, SP and BR scored insect-based proteins higher than cultured meat. Conversely, respondents from the DR indicated that their predicted opinions were in favour of plant-based proteins, followed by cultured meat, followed by insect-based proteins, in regards to healthiness, safety, nutritiousness, sustainability, and expected taste and cost. Interestingly, respondents from the UK and BR indicated a higher taste preference for cultured meat, while in all other instances, plant-based proteins received the highest preference score. While the UK respondents believed that insect-based proteins were healthy, safe, nutritious and sustainable, with scores significantly higher than in other countries, those in the DR mostly disagreed, thus, presenting the lowest scores. Table 8 shows the significant differences in the appreciation of plant-, culturedmeat and insect-based proteins among the UK, SP, BR and the DR.

Table 8. Opinions about characteristics of the plant-, cultured-meat and insect-based proteins expressed as mean \pm standard deviation. ANOVA by rows evaluates the significant differences for each characteristic among countries. Different superscript letters across the same variable denote a significant difference between countries $(p<0.05)$, n.s. = "not significant".

\begin{tabular}{lllllrr}
\hline Variable & $\begin{array}{l}\text { United } \\
\text { Kingdom }\end{array}$ & Spain & Brazil & $\begin{array}{l}\text { Dominican } \\
\text { Republic }\end{array}$ & F & $p$ \\
\hline Healthiness of plant-based & $4.16 \pm 0.77^{\mathrm{a}}$ & $4.36 \pm 0.69^{\mathrm{b}}$ & $4.06 \pm 0.83^{\mathrm{a}}$ & $4.38 \pm 0.84^{\mathrm{b}}$ & 7.402 & 0.000 \\
Safe to eat plant-based & $4.22 \pm 0.70^{\mathrm{a}}$ & $4.15 \pm 0.80^{\mathrm{a}}$ & $3.89 \pm 0.83^{\mathrm{b}}$ & $4.21 \pm 0.84^{\mathrm{a}}$ & 7.245 & 0.000 \\
Plant-based proteins are nutritious & $4.21 \pm 0.75^{\mathrm{a}}$ & $4.21 \pm 0.77^{\mathrm{a}}$ & $4.03 \pm 0.80^{\mathrm{b}}$ & $4.29 \pm 0.74^{\mathrm{a}}$ & 3.581 & 0.014 \\
Plant-based more sustainable & $3.67 \pm 1.12^{\mathrm{a}}$ & $3.30 \pm 1.00^{\mathrm{b}}$ & $3.37 \pm 1.21^{\mathrm{b}}$ & $3.67 \pm 1.12^{\mathrm{a}}$ & 7.165 & 0.000 \\
Plant-based tastier than meat & $2.41 \pm 1.15^{\mathrm{a}}$ & $2.52 \pm 1.06^{\mathrm{a}}$ & $1.93 \pm 0.89^{\mathrm{c}}$ & $2.85 \pm 1.12^{\mathrm{b}}$ & 23.369 & 0.000 \\
Plant-based proteins cheaper & $3.34 \pm 1.06^{\mathrm{a}}$ & $3.31 \pm 1.14^{\mathrm{b}}$ & $3.16 \pm 1.20^{\mathrm{a}}$ & $3.49 \pm 1.08^{\mathrm{a}}$ & 3.271 & 0.021 \\
\hline Healthiness of cultured meat & $3.06 \pm 0.91$ & $2.81 \pm 0.96$ & $2.94 \pm 0.87$ & $2.88 \pm 0.90$ & n.s. & n.s. \\
Safe to eat cultured meat & $3.13 \pm 0.92^{\mathrm{a}}$ & $2.81 \pm 0.95^{\mathrm{b}}$ & $2.94 \pm 0.88^{\mathrm{b}}$ & $3.18 \pm 0.92^{\mathrm{a}}$ & 6.254 & 0.000 \\
Cultured meat is nutritious & $3.34 \pm 0.87^{\mathrm{a}}$ & $3.16 \pm 0.94^{\mathrm{ab}}$ & $3.25 \pm 0.83^{\mathrm{a}}$ & $3.03 \pm 1.03^{\mathrm{a}}$ & 3.153 & 0.024 \\
Cultured meat more sustainable than & $3.08 \pm 1.10$ & $2.99 \pm 1.08$ & $3.00 \pm 0.97$ & $2.81 \pm 0.99$ & n.s. & n.s.
\end{tabular}




\begin{tabular}{lcccccc}
$\begin{array}{l}\text { Cultured meat tastier than traditional } \\
\text { meat }\end{array}$ & $2.57 \pm 0.81^{\mathrm{a}}$ & $2.36 \pm 0.84^{\mathrm{b}}$ & $2.41 \pm 0.85^{\mathrm{b}}$ & $2.65 \pm 0.99^{\mathrm{a}}$ & 4.062 & 0.007 \\
$\begin{array}{l}\text { Cultured meat cheaper than traditional } \\
\text { meat }\end{array}$ & $2.57 \pm 0.93^{\mathrm{ac}}$ & $2.65 \pm 1.00^{\mathrm{a}}$ & $2.40 \pm 0.88^{\mathrm{c}}$ & $2.86 \pm 1.04^{\mathrm{b}}$ & 6.548 & 0.000 \\
\hline $\begin{array}{l}\text { Healthiness of insect-based } \\
\text { Safe to eat insect-based }\end{array}$ & $3.58 \pm 1.04^{\mathrm{a}}$ & $3.34 \pm 0.97^{\mathrm{b}}$ & $3.31 \pm 0.88^{\mathrm{b}}$ & $2.71 \pm 1.15^{\mathrm{c}}$ & 16.014 & 0.000 \\
$\begin{array}{l}\text { Insect-based proteins are nutritious } \\
\text { Insects more sustainable than meat }\end{array}$ & $3.50 \pm 0.98^{\mathrm{a}}$ & $3.09 \pm 0.99^{\mathrm{b}}$ & $2.92 \pm 0.89^{\mathrm{b}}$ & $2.45 \pm 1.10^{\mathrm{c}}$ & 26.766 & 0.000 \\
$\begin{array}{l}\text { Insect-based protein tastier than } \\
\text { traditional meat }\end{array}$ & $3.53 \pm 1.14^{\mathrm{a}}$ & $3.49 \pm 0.98^{\mathrm{b}}$ & $3.51 \pm 0.88^{\mathrm{b}}$ & $2.74 \pm 1.17^{\mathrm{c}}$ & 21.232 & 0.000 \\
$\begin{array}{l}\text { Insect-based cheaper than traditional } \\
\text { meat }\end{array}$ & $2.29 \pm 0.92^{\mathrm{a}}$ & $2.30 \pm 0.93^{\mathrm{a}}$ & $3.16 \pm 1.06^{\mathrm{b}}$ & $2.43 \pm 1.18^{\mathrm{c}}$ & 22.885 & 0.000 \\
& $3.28 \pm 1.02^{\mathrm{a}}$ & $3.16 \pm 1.02^{\mathrm{a}}$ & $3.13 \pm 1.00^{\mathrm{a}}$ & $2.89 \pm 1.14^{\mathrm{b}}$ & 3.632 & 0.013 \\
\hline
\end{tabular}

355

356

357

358

359

360

361

362

363

364

365

\subsection{Principal component analysis results}

The PCA reduction of the variables revealed four new components for plant-based variables, related to i) Alternative to meat product characteristics, ii) Food technology neophobia, iii) Buying decisions (responses related to the healthiness of food and environmental consequences of buying food) and iv) Convenience-buying decision and food neophobia (Table 9).

Table 9. Eigenvectors in the principal component analysis of the plant-based protein variables. Rotated components using varimax. The selected predictor was the variable with the highest loads.

\begin{tabular}{|c|c|c|c|c|}
\hline \multirow[b]{2}{*}{ Variables } & \multicolumn{4}{|c|}{ Principal components } \\
\hline & 1 & 2 & 3 & 4 \\
\hline FNS & & & & 0.589 \\
\hline FTNS & & 0.802 & & \\
\hline Impact of the healthiness of food choices & & & 0.527 & \\
\hline Convenience in relation of the food & & & & 0.817 \\
\hline Environmental impact of food choices & & & 0.865 & \\
\hline Plant-based protein characteristics & 0.865 & & & \\
\hline Plant-based versus traditional characteristics & 0.829 & & & \\
\hline $\begin{array}{l}\text { Type of variables represented by each } \\
\text { component }\end{array}$ & $\begin{array}{l}\text { Product } \\
\text { characteristics }\end{array}$ & $\begin{array}{l}\text { Food } \\
\text { technology } \\
\text { neophobia }\end{array}$ & $\begin{array}{l}\text { Buying } \\
\text { decisions }\end{array}$ & $\begin{array}{l}\text { Convenience- } \\
\text { buying decision } \\
\text { and } \\
\text { food neophobia }\end{array}$ \\
\hline
\end{tabular}

$\overline{\text { FNS }}=$ Food neophobia scale, FTNS=Food technology neophobia scale

food neophobia

The PCA reduction of the variables of the cultured meat- and insect-based protein variables revealed three new components for each alternative. These components were related to i) Product characteristics, ii) Buying decisions and iii) Neophobia (Table 10). 
Table 10. Eigenvectors in the principal component analysis of the cultured meat and insect-based protein variables. Rotated components using varimax. The selected predictor was the variable with the highest loads.

\begin{tabular}{|c|c|c|c|c|}
\hline \multirow[b]{2}{*}{ Variables related to cultured meat proteins } & \multicolumn{2}{|c|}{ Principal components } & \multicolumn{2}{|r|}{376} \\
\hline & 1 & 2 & 3 & 377 \\
\hline FNS & & & 0.690 & \\
\hline FTNS & & & 0.745 & 378 \\
\hline Impact of the healthiness of food choices & & 0.616 & & 379 \\
\hline Convenience in relation of the food & & 0.673 & & \\
\hline Environmental impact of the food choices & & 0.662 & & 380 \\
\hline Cultured meat characteristics & 0.875 & & & 381 \\
\hline Cultured meat versus traditional characteristics & 0.883 & & & \\
\hline Variables related to insect-based proteins & 1 & 2 & 3 & 382 \\
\hline FNS & & & 0.653 & 383 \\
\hline FTNS & & & 0.756 & \\
\hline Impact of the healthiness of food choices & & 0.510 & & 384 \\
\hline Convenience in relation of the food & & 0.696 & & 385 \\
\hline Environmental impact of the food choices & & 0.714 & & 303 \\
\hline Insect-based protein characteristics & 0.903 & & & 386 \\
\hline Insect-based protein versus traditional characteristics & 0.886 & & & 387 \\
\hline Type of variables represented by each component & $\begin{array}{l}\text { Product } \\
\text { characteristics }\end{array}$ & $\begin{array}{l}\text { Buying } \\
\text { decisions }\end{array}$ & $\mathrm{Neo}$ & $\begin{array}{r}\text { hy8i8 } \\
389\end{array}$ \\
\hline
\end{tabular}

FNS $=$ Food neophobia scale, FTNS=Food technology neophobia scale

\subsection{Binary logistic regression results}

The WTPu plant-based proteins models (Table 11) revealed that the healthiness, safety and nutritional characteristics were the most important descriptor regarding WTPu plant-based proteins in the UK, SP and BR. Nevertheless, in the DR, the most important factor was the 'food technology neophobia'. In the DR, the 'convenience of the food' and 'food neophobia' were negatively correlated with WTPu. The remaining variables were positively correlated.

The goodness-of-fit of the predictive model (Table 11 footnotes) indicates that in SP, that there is a $95.0 \%$ likelihood of predicting the WTPu plant-based proteins, based on the plant-based characteristics of healthiness, safety and nutritional content. A similar prediction can be made for the DR consumers, with a likelihood of $89.5 \%$.

The exponentiated values of the coefficients $\left[\operatorname{Exp}\left(\beta_{i}\right)\right]$ representing the ratio change in the odds of the WTPu for a unit change in the score given by respondents in the value of the respective predictor, all other things being equal, were calculated. In SP, the estimated coefficient of the predictor product characteristics was 1.686 , and the exponentiated value was 5.397 (Table 11). Considering an initial 0.5 probability $(p)$ (i.e., 50\% probability of responding "Yes, I would purchase plant-based proteins" against 50\% probability of responding "No, I wouldn't purchase") at a certain value of the characteristics of healthiness, safety and nutritiousness of plant-based, the corresponding odds of 1 for the WTPu $[\mathrm{O}(\mathrm{WTPu})]$ would be $\mathrm{O}(\mathrm{WTPu})=p /(1-p)$ for that subject. Since the odds ratio for the product characteristics was 5.397 for SP respondents (Table 13), the odds of 1 would become 5.397 if the score given by the respondent to product characteristics increased by a unit value. Now, the probability 
417 of the WTPu will be 0.843 , which is $68.74 \%$ higher than the initial 0.5 probability

418 (Mathew, Jha \& Rawat, 2009).

419

420

421

422
423

424

425

426

427

428

429

430

431

432

433

434

435

436

437

438

439

440

441

442

443

444

445

446

447

448

Table 11. Consumers' willingness to purchase (WTPu) the plant-based proteins in the United

Kingdom(UK), Spain(SP), Brazil(BR) and the Dominican Republic(DR) using coefficient estimates and diagnostics from binary logistic regression and Wald forward stepwise method.

\begin{tabular}{llcccc}
\hline Determinant factor & $\beta$ & $\begin{array}{l}\text { Standard } \\
\text { error }\end{array}$ & Wald & Significance & $\operatorname{Exp}\left(\beta_{i}\right)$ \\
\hline $\begin{array}{l}\text { United Kingdom WTPu plant-based model } \\
\text {-Product characteristics }\end{array}$ & 1.115 & 0.300 & 13.833 & 0.000 & 3.048 \\
$\begin{array}{l}\text {-Buying decisions } \\
\text { Spain WTPu plant-based model }\end{array}$ & 0.925 & 0.337 & 7.577 & 0.006 & 2.526 \\
-Product characteristics & 1.686 & 0.556 & 9.198 & 0.002 & 5.397 \\
$\begin{array}{l}\text { Brazil WTPu plant-based model } \\
\text {-Product characteristics }\end{array}$ & 1.436 & 0.253 & 32.12 & 0.000 & 4.203 \\
$\begin{array}{l}\text { Dominican Republic WTPu plant-based model } \\
\text {-Technology neophobia }\end{array}$ & 1.249 & 0.573 & 4.760 & 0.029 & 3.487 \\
-Convenience-buying decision and neophobia & -1.215 & 0.489 & 6.180 & 0.013 & 0.297 \\
\hline
\end{tabular}

Goodness-of-fit statistics of the model associated with WTPu plant-based proteins in the UK: -2Log likelihood statistic $=221.19$; Overall success rate $=70.0 \%$

Goodness-of-fit statistics of the model associated with WTPu plant-based proteins in SP: -2Log likelihood statistic $=68.55$; Overall success rate $=95.0 \%$

Goodness-of-fit statistics of the model associated with WTPu plant-based proteins in BR: -2Log likelihood statistic $=256.24$; Overall success rate $=68.1 \%$

Goodness-of-fit statistics of the model associated with WTPu plant-based proteins in the DR: -2Log likelihood statistic $=79.53$; Overall success rate $=89.5 \%$

The healthiness, safety and nutritional characteristics of cultured meat were the most important factor in predicting WTPu in all countries (Table 12), with all the variables being positively correlated.

The goodness-of-fit of the predictive model (Table 12 footnotes) indicated that in BR, there was a $90.7 \%$ likelihood of predicting the WTPu cultured meat proteins, based on the cultured meat characteristics such as healthiness, safety and nutritional content. The exponentiated value was 14.169 (Table 12) for a Brazilian with a 50\% probability of WTPu cultured meat at a certain product characteristics value $(50 \% \mathrm{WTPu}$ against a $50 \%$ not to purchase cultured meat). According to the model, the odds of 1 will become 14.169, if the score of the cultured meat product characteristics increases by one unit value. Now, the probability of the Brazilian to WTPu will be 0.934 , which is $86.82 \%$ higher than the initial $50 \%$ probability.

Table 12. Consumers' willingness to purchase (WTPu) cultured meat in the United Kingdom(UK), Spain(SP), Brazil(BR) and the Dominican Republic( DR) using coefficient estimates and diagnostics from binary logistic regression and Wald forward stepwise method.

\begin{tabular}{llllll}
\hline Determinant factor & $\beta$ & $\begin{array}{l}\text { Standard } \\
\text { error }\end{array}$ & Wald & Significance & $\operatorname{Exp}\left(\beta_{i}\right)$ \\
\hline $\begin{array}{l}\text { United Kingdom WTPu cultured meat model } \\
\text {-Product characteristics }\end{array}$ & 1.307 & 0.333 & 15.441 & 0.000 & 3.695 \\
$\begin{array}{l}\text { Spain WTPu cultured meat model } \\
\text {-Product characteristics }\end{array}$ & 1.138 & 0.231 & 24.282 & 0.000 & 3.121 \\
$\begin{array}{l}\text { Brazil WTPu cultured meat model } \\
\text {-Product characteristics }\end{array}$ & & & & & \\
-Neophobia & 2.651 & 0.579 & 20.938 & 0.000 & 14.169 \\
$\begin{array}{l}\text { Dominican Republic WTPu cultured meat model } \\
\text {-Product characteristics }\end{array}$ & -1.932 & 0.593 & 10.613 & 0.001 & 6.901 \\
\hline
\end{tabular}


Goodness-of-fit statistics of the model associated with WTPu cultured meat proteins in the UK: -2Log likelihood statistic $=190.785$; Overall success rate $=72.8 \%$

Goodness-of-fit statistics of the model associated with WTPu cultured meat proteins in SP: -2Log likelihood statistic $=242.296$; Overall success rate $=69.5 \%$

Goodness-of-fit statistics of the model associated with WTPu cultured meat proteins in BR: -2Log likelihood statistic $=104.564$; Overall success rate $=90.7 \%$

Goodness-of-fit statistics of the model associated with WTPu cultured meat proteins in the DR: -2Log likelihood statistic $=161.287$; Overall success rate $=71.4 \%$

The models for WTPu insect-based proteins (Table 13) revealed the 'insect product characteristics' was the most important factor regarding WTPu insect-based proteins, in

460 all the countries. All the variables were positively correlated. The goodness-of-fit of the predictive models indicated that the UK (overall success rate $=78.9 \%$ ), BR (overall success rate $=93.1 \%$ ) and the DR (overall success rate $=78.9 \%$ ) models for WTPu had a predictive ability. When the scores of the healthiness, safety and nutritional characteristics of insects-based product increased one unit value, the probability of the WTPu would be 0.843 in the UK, 0.861 in BR and 0.793 in the DR, which were $68.70 \%, 72.12 \%$ and $58.56 \%$, respectively, higher than the initial $50 \%$ probability of WTPu versus not WTPu insect-based products.

Table 13. Consumers' willingness to purchase (WTPu) insect-based proteins in the United Kingdom(UK), Spain(SP), Brazil(BR) and the Dominican Republic(DR) using coefficient estimates and diagnostics from binary logistic regression and Wald forward stepwise method.

\begin{tabular}{lcccc}
\hline Determinant factor & $\beta$ & $\begin{array}{l}\text { Standard } \\
\text { error }\end{array}$ & Wald & Significance \\
\hline $\begin{array}{l}\text { United Kingdom WTPu insect-based proteins model } \\
\text {-Product characteristics }\end{array}$ & 1.684 & 0.324 & 27.075 & 0.000 \\
$\begin{array}{l}\text { Spain WTPu insect-based proteins model } \\
\text {-Product characteristics }\end{array}$ & 0.980 & 0.208 & 22.262 & 0.000 \\
$\begin{array}{l}\text { Brazil WTPu insect-based proteins model } \\
\text {-Product characteristics }\end{array}$ & 1.820 & 0.447 & 21.853 & 0.000 \\
$\begin{array}{l}\text { Dominican Republic WTPu insect proteins model } \\
\text {-Product characteristics }\end{array}$ & 1.342 & 0.287 & 16.591 & 0.000 \\
\hline
\end{tabular}

Goodness-of-fit statistics of the model associated with WTPu insect-based proteins in the UK: -2Log likelihood statistic $=170.863$; Overall success rate $=78.9 \%$

Goodness-of-fit statistics of the model associated with WTPu insect-based proteins in SP: -2Log likelihood statistic $=248,293$; Overall success rate $=62.5 \%$

Goodness-of-fit statistics of the model associated with WTPu insect-based proteins in BR: -2Log likelihood statistic $=88.429$; Overall success rate $=93.1 \%$

Goodness-of-fit statistics of the model associated with WTPu insect-based proteins in the DR: -2Log likelihood statistic $=124.231$; Overall success rate $=78.9 \%$

\section{Discussion}

The aim of this study was to provide insight into consumer preferences and the WTPu three alternative dietary protein sources (plant-, cultured meat- and insect-based proteins) in the UK, SP, BR and the DR. Furthermore, we aimed to determine the important factors most likely influencing the WTPu that would predict future WTPu.

Several consumers from across the countries included in this study believed that the nutritional benefits of meat could readily be matched by alternative protein sources, ranging from $20.8 \%$ (in BR) to $53.8 \%$ (in the UK). However, that was fewer than the $72 \%$ reported by Verbeke et al. (2015) in their study in Flanders (Belgium). The most 
preferred alternative source to meat protein with regards to WTPu was plant-based proteins but in declining order of preference for the $\mathrm{UK}<\mathrm{SP}<\mathrm{BR}<$ the $\mathrm{DR}$. In contrast, the lowest WTPu meat alternative was insect-based proteins, in both BR and the DR. Both were representative of the least economically-developed countries included in this study, which were also the countries with the greatest increased rates in meat consumption over the last decades (FAO, 2019). The notion of greater increased meat consumption is also noted by Sabate \& Soret (2014), who suggested that meat consumption has increased by $300 \%$ in developing countries since the early 1960 s while worldwide consumption had increased by only $62 \%$ in the same period. In Latin America, meat tends to be a relatively cheap commodity because meat production is a prominent agricultural activity (Austin, 2010). This statement holds particularly true in $\mathrm{BR}$, which has the largest commercial bovine herd in the world and is also a major exporter of not only beef but other meats too. However, about $80 \%$ of all beef produced in Brazil is consumed domestically (ABIEC, 2019).

The UK respondents indicated a greater willingness to substitute meat with alternative dietary protein sources compared with SP, BR or the DR, by suggesting that meat does not necessarily have an important role in a healthy and balanced diet. Overall, the UK respondents' perception of the characteristics of the insect-based products was significantly higher and differed from those of the SP, BR and the DR respondents. The DR respondents had significantly lower WTPu insects as food. This outcome is probably directly attributable to the notion that the respondents in the DR also indicated insects as significantly less safe, less healthy and less nutritious than any other protein source. Furthermore, the DR respondents did not perceive insects as a more sustainable source of protein than meat. These findings are in agreement with the prediction by Tilman and Clark (2014) that developing cultures would continue to prefer a greater proportion of meat in their diet and avoid protein sources that are locally perceived as unaligned with an affluent status. As such, when annual incomes increase in less economically-developed countries, the per capita daily demand for meat protein also increased (Tilman \& Clark, 2014). Conversely, the respondents from the UK, which belongs to the highest economic group studied, demonstrated the greatest readiness to substitute conventional meat for the three alternatives and to achieve low-meat diets.

The PCA reduction of the psychographic variables differed for plant-based, cultured meat and insect-based products (refer tables 9 and 10). This may be explained by the recent history of some of these products. Plant-based alternative options have been more well-established in the retail market, thus offering a varied range of products (de Boer et al., 2014; Sabaté \& Soret, 2014; Tilman \& Clark, 2014). Instead, insect-based proteins have only recently entered the retail market, while cultured meat is still to make its full, widespread commercial entry into it. For the plant-based alternative, the 'neophobia' variable may become blurred into the consumers' buying decisions because of its common availability (Pliner \& Salvy, 2006); while 'food technology neophobia' takes prominence. For potential product alternatives with immature markets, the neophobia 
535 factor is of relevance and is represented by its own importance component (Schösler et 536 al., 2012).

The consumers' perceptions of healthiness, safety and nutritional characteristics of the alternative dietary proteins and/or the higher sustainability, taste and lower price compared with conventional meat showed to be the most important factors influencing consumers' WTPu in the UK, SP and BR, which is in agreement with the findings of

542 Verbeke et al. (2015). However, this did not apply to the Dominicans WTPu plant-

543 based proteins. Instead 'food technology neophobia' and 'buying decisions' played a

544 more prominent role in shaping their WTPu plant-based proteins. The 'buying

545 decisions' also appeared important in influencing a WTPu plant-based proteins in the

546 UK, which agrees with the arguments of Gerber et al. (2013), Sadler (2004) and Tilman

547 and Clark (2014) while 'neophobia' influenced the WTPu of cultured meat in BR.

For the future development of alternatives to meat proteins, the focus should be given to healthiness, safety and nutritional characteristics of the alternatives and/or the higher sustainability, taste and lower price compared with conventional meat. The models predicted that, in the Brazilian case, when the perception of healthiness, safety and nutritiousness for cultured meat increased by one-unit, the probability of the willingness to purchase would increase by $86.8 \%$. In Spain, the models indicated that one-unit increase in the belief that plant-based proteins were healthy, safe and nutritious would cause the probability of the willingness to purchase to go up by $68.7 \%$. Furthermore, one-unit increase in the perception of healthiness, safety and nutritional content of insect-based product characteristics would cause an increase of the probability of the willingness to purchase by $68.7 \%$ in the United Kingdom, $72.1 \%$ in Brazil and 58.6\% in the Dominican Republic.

The transition to alternative dietary proteins may vary, depending on the alternative proteins readily available in the market (Schösler et al., 2012) and the country in which the transition is observed (Schnettler et al., 2013). Despite this, some interesting predictions based on our models could be made to predict a transition to a low-meat diet. To encourage meat substitution, future research should focus on improving the specific perception of the characteristics of healthiness, safety and nutritional content of the commodity and/or their higher sustainability, taste and lower price compared with conventional meat (Graça et al., 2015). While our research focussed on the WTPu alternative dietary protein sources, future research could focus on investigating consumers' feelings, beliefs, attitudes and motivations for the transition to low-meat diets; using, for instance, qualitative methods, such as focus groups. Furthermore, it would be of interest to capture the consumers' attitudes towards meat alternatives by analysing the product characteristics with respect to their shapes, formats and types of food carriers (i.e., insects incorporated in pasta or into chocolate bars, etc.), as proposed by Lombardi et al. (2018). Finally, further insights could be provided by studies

577 examining how consumers' motives and preferences towards alternatives to dietary meat proteins may vary across different contexts (e.g., consumption moment, purchase 
occasion, usage situation). The media information in the countries is also of interest to be analysed because various authors have highlighted the influence of media coverage on the consumers' attitudes towards novel and alternative dietary protein sources (Goodwin \& Shoulders, 2013; Lombardi et al., 2018). In this sense, the current widespread media information circulating Europe may influence the attitudes, especially towards insect-based products (Algemeen Dagblad, 2016; Der Standard, 2018; La Vanguardia, 2018; The Guardian, 2015).

Our research approach has given rise to several limitations that restrict the scope of generalisations. Firstly, a convenience sampling method in the distribution of the questionnaires was used. While convenience sampling is affordable, easy and the subjects are readily contactable (Etikan, Musa \& Alkassim, 2016), it still relies on potential subjects to respond to the questionnaire. An alternative method would have been to use paid subjects through an online market research company (e.g., Kellershohn, Walley \& Vriesekoop, 2018); however, the use of pre-screened subjects through an online market research company does not necessarily result in more truthful data. An argument could be made that respondents in a convenience sample participate in the study because they want to voice their opinion on the given topic, whereas respondents recruited through an online market research company participate because of a financial gain and may not have an interest in the topic. Secondly, the selective bias and the ambiguity of the inferred research questions could have limited the scope of generalisation of the findings of this study. However, it should be acknowledged that when answering a survey, respondents are keen to concentrate fully on the specific environment, describing attitudes that may vary beyond what would occur in a typical market environment (Yen, 2009). Thirdly, the dichotomisation of the WTPu variable although common, because it greatly simplifies the statistical analysis and leads to easy interpretation and presentation of results is gained at some cost. Firstly, much information is lost, so the statistical power to detect a relation between the variable and subject outcome is reduced. It may also increase the risk of a positive result being a false positive. Secondly, one may seriously underestimate the extent of variation in outcome between groups, such as the risk of some event, and considerable variability may be subsumed within each group (Altman \& Royston, 2006). Another minor shortcoming stems from the specific nature of the meat alternatives analysed, which, for cultured meat and insects as food (Loughnan, Bastian \& Haslam, 2014), could be unknown by the respondents due to the immaturity of these markets. As such, it might be difficult for the respondents to imagine what it would be like as an alternative protein source, which means that describing attitudes towards unfamiliar products could be a challenge.

\section{Conclusions}

The willingness to purchase non-meat dietary protein namely plant-, cultured meat- and insect-based proteins, varied from alternative-to-alternative, and country-to-country. The most probable willingness to purchase alternatives to meat was found to be plant-based 
proteins. Plant-based proteins tend to be more widely available than the other alternative protein sources, as well as being a mature product in the market. The respondents in the United Kingdom and Spain showed a greater readiness to replace traditional meats with the three protein alternatives than those in Brazil and the Dominican Republic which represented the least economically-developed countries included in this study. When comparing alternative proteins to traditional meat, the respondents attributed more importance to meat characteristics such as healthiness, safety and nutritional content, and/or higher sustainability, taste and lower price than the buying decisions or neophobia per se. The models predicted that a one unit increase in the plant-based the healthiness, safety and nutritional content might be associated with a $68.7 \%$ increase in the probability of willingness to purchase plant-based proteins in Spain. A one-unit stronger belief in the cultured meat healthiness, safety and nutritional content may be associated with an $86.8 \%$ increase in the probability of willingness to purchase cultured meat in Brazil. A one-unit stronger belief in the perception of the insect-based characteristics of healthiness, safety and nutritional content might be associated with a $68.7 \%$ increase in the probability of willingness to purchase insect-based products in the United Kingdom, a 72.1\% in Brazil and a 58.6\% in the Dominican Republic. The future development of the three alternatives to meat proteins in the economic groups studied should focus on the perceived healthiness, safe and nutritional characteristics and/or higher sustainability, taste and lower price of the alternative dietary protein sources compared with meat.

\section{Declarations of interest: none}

Funding sources: This research has been financially supported by Harper Adams University and the University of Valladolid

\section{References}

- ABIEC Associação Brasileira das Indústrias Exportadoras de Carne. Estatísticas: Balanço da pecuária. (2019). http://abiec.siteoficial.ws/images/upload/sumario-pt010217.pdf/ Accessed 10 June 2019.

- Adámek, M., Adámková, A., Mlček, J., Borkovcová, M., \& Bednářová, M. (2018). Acceptability and sensory evaluation of energy bars and protein bars enriched with edible insect. Slovak Journal of Food Sciences, 12(1), 431-437. https://doi.org/10.5219/925.

- Algemeen Dagblad. Jumbo legt eetbare insecten in schappen. (2016). https://www.ad.nl/economie/jumbo-legt-eetbare-insecten-in-schappen a $75 \mathrm{e} 63 \mathrm{f} 4 /$ Accessed 10 June 2019.

- Altman, D. G., \& Royston, P. (2006). The cost of dichotomising continuous variables. BMJ, 332(7549), 1080. http://doi.org/10.1136/bmj.332.7549.1080.

- Arshad, M. S., Javed, M., Sohaib, M., Saeed, F., Imran, A., \& Amjad, Z. (2017). Tissue engineering approaches to develop cultured meat from cells: A mini review. Cogent Food \& Agriculture, 3(1),1320814. http://10.1080/23311932.2017.1320814.

- Austin, K. (2010). The "Hamburger Connection" as ecologically unequal exchange: A cross-national investigation of beef exports and deforestation in less-developed countries. Rural Sociology, 75(2), 270-299. https://doi.org/10.1111/j.15490831.2010.00017.x. 
667 - Bryant, C., \& Barnett, J. (2018). Consumer acceptance of cultured meat: A

$668 \quad$ systematic review. Meat Science, 143, 8-17.

669 https://doi.org/10.1016/j.meatsci.2018.04.008.

670 - Candel, M. J. J. M. (2001). Consumers' convenience orientation towards meal

671 preparation: Conceptualization and measurement. Appetite, 36, 15-28. http://

672 doi.org/10.1006/appe.2000.0364.

673 - Clarys, P., Deliens, T., Huybrechts, I., Deriemaeker, P., Vanaelst, B., De Keyzer,

674 W., Hebbelinck, M., \& Mullie, P. (2014). Comparison of nutritional quality of the

675 vegan, vegetarian, semi-vegetarian, pesco-vegetarian and omnivorous diet.

$676 \quad$ Nutrients, 6(3), 1318-1332. http://doi.org/10.3390/nu6031318.

677 - Cox, D. N., \& Evans, G. (2008). Construction and validation of a psychometric

678 scale to measure consumers' fears of novel food technologies: the food technology

679 neophobia scale. Food Quality and Preference, 19, 704-710.

680 http://doi.org/10.1016/j.foodqual.2008.04.005.

681 - de Boer, J., \& Aiking, H. (2011). On the merits of plant-based proteins for global

682 food security. Marrying macro and micro perspectives. Ecological Economics,

683 70(7), 1259-1265. http://doi.org/10.1016/j.ecolecon.2011.03.001.

684 - de Boer, J., Hoogland, C. T., \& Boersema, J. J. (2007). Towards more sustainable

685 food choices. Value priorities and motivational orientations. Food Quality and

686 Preference, 18, 985-996. http://doi.org/10.1016/j.foodqual.2007.04.002.

687 - de Boer, J., Schösler, H., \& Aiking, H. (2014). "Meatless days" or "less but better"?

688 Exploring strategies to adapt Western meat consumption to health and sustainability

689 challenges. Appetite, 76, 120-128. http://dx.doi.org/10.1016/j.appet.2014.02.002.

690 - Der Standard. Essbare Insekten Ekel Food oder Nahrung der Zukunft. (2018).

691 https://derstandard.at/2000072388721/Essbare-Insekten-Ekel-Food-oder-Nahrung-

692 der-Zukunft/Accessed 10 June 2019.

693 - Drewnowski, A., \& Gomez-Carneros, C. (2000). Bitter taste, phytonutrients, and the

694 consumer: a review. The American Journal of Clinical Nutrition, 72(6), 1424-

695 1435. https://doi.org/10.1093/ajcn/72.6.1424.

696 - Etikan, I., Musa, S. A., \& Alkassim, R.S. (2016). Comparison of convenience

697 sampling and purposive sampling. American journal of theoretical and applied

698 statistics, 5(1), 1-4. https://doi.org/10.11648/j.ajtas.

699 - FAO United Nations Food and Agricultural Organization. Census data. (2019).

700 http://www.fao.org/faostat/en/?\#data/ Accessed 10 June 2019.

701 - Foer, J. S. (2010). Eating animals. London: Penguin Books.

702 - Gerber, P. J., Steinfeld, H., Henderson, B., Mottet, A., Opio, C., \& Dijkman, J.

703 (2013). Tackling climate change through livestock. A global assessment of

704 emissions and mitigation opportunities. Rome: Food and Agriculture Organization

705 of the United Nations (FAO).

706 - Goodwin, J. N., \& Shoulders, C. W. (2013). The future of meat: A qualitative

707 analysis of cultured meat media coverage. Meat Science, 95, 445-450.

708 http://doi.org/10.1016/j.meatsci.2013.05.027. 
- Graça, J., Oliveira, A., \& Cardoso, M. M. (2015). Meat, beyond the plate. Datadriven hypotheses for understanding consumer willingness to adopt a more plantbased diet. Appetite, 90, 80-90. http://doi.org/10.1016/j.appet.2015.02.037.

- Hayley, A., Zinkiewicz, L., \& Hardiman, K. (2015). Values, attitudes, and frequency of meat consumption. Predicting meat-reduced diet in Australians. Appetite, 84, 98-106. http://doi.org/10.1016/j.appet.2014.10.002.

- Herman, C. P., \& Polivy, J. (2008). External cues in the control of food intake in humans. The sensory-normative distinction. Physiology \& Behavior, 94, 722-728. http://doi.org/10.1016/j.physbeh.2008.04.014.

- Hoek, A. C., Luning, P. A., Weijzen, P., Engels, W., Kok, F. J., \& de Graaf, C. (2011). Replacement of meat by meat substitutes. A survey on person- and product related factors in consumer acceptance. Appetite, 56, 662-673. http://doi.org/10.1016/j.appet.2011.02.001.

- House, J. (2016). Consumer acceptance of insect-based foods in the Netherlands: Academic and commercial implications. Appetite, 107, 47-58. http://doi.org/ 10.1016/j.appet.2016.07.023.

- Keefe, L. M. (2018). \# FakeMeat: How big a deal will animal meat analogs ultimately be? Animal Frontiers, 8(3), 30-37. https://doi.org/10.1093/af/vfy011.

- Kellershohn, J., Walley, K., \& Vriesekoop, F. (2018). Ontario menu calorie labelling legislation: Consumer calorie knowledge six months post-implementation. Canadian Journal of Dietetic Practice and Research, 79(3), 129-132.

- La Vanguardia. Los insectos comestibles una alternativa de fututo. (2018). http://www.lavanguardia.com/natural/20180718/45909697841/los-insectoscomestibles-una-alternativa-de-futuro.html/Accessed 10 June 2019.

- Lombardi, A., Vecchio, R., Borrello, M., Caracciolo, F., \& Cembalo, L. (2018). Willingness to pay for insect-based food: the role of information and carrier. Food Quality and Preference, 72, 177-187. http://doi.org/10.1016/j.foodqual.2018.10.001.

- Loughnan, S., Bastian, B., \& Haslam, N. (2014). The psychology of eating animals. Current Direct Psychology Science, 23(2), 104-108. http://doi.org/10.1177/0963721414525781.

- Mathew, J., Jha, V. K. \& Rawat, G. S. (2009). Landslide susceptibility zonation mapping and its validation in part of Garhwal Lesser Himalaya, India, using binary logistic regression analysis and receiver operating characteristic curve method. Landslides, 6, 17. https://doi.org/10.1007/s10346-008-0138-z.

- Pliner, P., \& Hobden, K. (1992). Development of a scale to measure the trait of food neophobia in humans. Appetite, 19, 105-120. http://doi.org/10.1016/01956663(92)90014-w.

- Pliner, P., \& Salvy, S. J. (2006). Food neophobia in humans. In R. Shepherd, \& M. Raats (Eds.), The psychology of food choice (pp. 75-92). Waalingford: CABI.

- Post, M. J. (2014). An alternative animal protein source: cultured beef. Annals of the New York Academy of Sciences, 1328, 29-33. http://doi.org/10.1111/nyas.12569. 
751 - Rahayu, S., Sugiarto, T., Madu, L., Holiawati, \& Subagyo, A. (2017). Application

752 of principal component analysis (PCA) to reduce multicollinearity exchange rate currency of some countries in Asia period 2004-2014. International Journal of Educational Methodology, 3(2), 75-83. http://doi.org/10.12973/ijem.3.2.75.

- Ramos-Elorduy, J. (1997). Insects: A sustainable source of food? Ecology of food and Nutrition, 36, 247-276. https://doi.org/10.1080/03670244.1997.9991519.

- Raphaely, T., \& Marinova, D. (2014). Flexitarianism. Decarbonising through flexible vegetarianism. Renewable Energy, 67, 90-96. http://doi.org/ 10.1016/j.renene.2013.11.030.

- Roberts, J. A. (1996). Green consumers in the 1990s: Profile and implications for advertising. Journal of Business Research, 36, 217-231. http://doi.org/10.1016/0148-2963(95)00150-6.

- Roininen, K., Lähteenmäki, L., \& Tuorila, H. (1999). Quantification of consumer attitudes to health and hedonic characteristics of foods. Appetite, 33(1), 71-88. http://dex.doi.org/10.1006/appe.1999.0232.

- Rothgerber, H. (2015). Can you have your meat and eat it too? Conscientious omnivores, vegetarians, and adherence to diet. Appetite, 84, 196-203. http://doi.org/ 10.1016/j.appet.2014.10.012.

- Sabaté, J. (2003). The contribution of vegetarian diets to health and disease. A paradigm shift? The American Journal of Clinical Nutrition, 78(3), 502S-507S. http://doi.org/10.1093/ajcn/78.3.502S.

- Sabaté, J., \& Soret, S. (2014). Sustainability of plant-based diets: back to the future. The American Journal of Clinical Nutrition, 100, 476S-482S. http://doi.org/ 10.3945/ajen.113.071522.

- Sadler, M. J. (2004). Meat alternatives - market developments and health benefits. Trends in Food Science \& Technology, 15, 250-260. https://doi.org/10.1016/j.tifs.2003.09.003.

- Schnettler, B., Crisóstomo, G., Sepúlveda, J., Mora, M., Lobos, G., \& Miranda, H. (2013). Food neophobia, nanotechnology and satisfaction with life. Appetite, 69, 71-79. http://doi.org/10.1016/j.appet.2013.05.014.

- Schösler, H., de Boer, J., \& Boersema, J. J. (2012). Can we cut out the meat of the dish? Constructing consumer-oriented pathways towards meat substitution. Appetite, 58, 39-47. http://doi.org/10.1016/j.appet.2011.09.009.

- Symmank, C., Mai, R., Hoffmann, S., Stok, F. M., Renner, B., Lien, N., \& Rohm, H. (2017). Predictors of food decision making: A systematic interdisciplinary mapping (SIM) review. Appetite, 110, 25-35. http://doi.org/10.1016/j.appet.2016.11.023.

- The Guardian. Eating insects should part sustainable diet future report. (2015). https://www.theguardian.com/environment/2015/nov/05/eating-insects-should-partsustainable-diet-future-report/ Accessed 10 June 2019.

- Tilman, D., \& Clark, M. (2014). Global diets link environmental sustainability and human health. Nature, 515, 518-522. http://doi.org/10.1038/nature13959.

- van Huis, A. (2017). New sources of animal proteins: edible insects. In Purslow, P. (Ed.), New aspects of meat quality (pp. 443-461). Oxford: Woodhead Publishing. 
- Verbeke, W. (2015). Profiling consumers who are ready to adopt insects as a meat substitute in a Western Society. Food Quality and Preference, 39, 147-155. http://doi.org/10.1016/j.foodqual.2014.07.008.

- Verbeke, W., Sans, P., \& Van Loo, E. J. (2015). Challenges and prospects for consumer acceptance of cultured meat. Journal of Integrative Agriculture, 14(2), 285-294. http://doi.org/10.1016/S2095-3119(14)60884-4.

- World Bank. World population statistics. (2019). https://datos.bancomundial.org/indicador/SP.POP.TOTL.FE.ZS?view=chart/ Accessed 10 June 2019.

- Yen, A. L. (2009). Edible insects: Traditional knowledge or western phobia. Entomological Research, 39, 289-298. https://doi.org/10.1111/j.17485967.2009.00239.x. 